\title{
Participation of the Women of Albania in Politics and Their Rights \\ Dr.Issa Erbaş
}

\author{
Shkolla e Lartë Hëna e Plotë Bedër, Tirana / Albania
}

ierbas@beder.edu.al

\section{Doi:10.5901/ajis.2014.v3n6p379}

\begin{abstract}
All Albanian women have the right to take part fully in all aspects of decision taking and decision making. This includes all kind of aspects of political life, family life, cultural and social affairs and the economy. Furthermore, without the active participation of Albanian women, efforts to end poverty are futile: sustainable social and economic development at community and national level and good governance is dependent on women taking part in all decision-making processes. Decision-making that is completely representative advantages not just women, but society as a whole: 'Without the active participation of women and the incorporation of women's perspectives at all levels of decision-making, the aims of development and peace cannot be accomplished. The women's rights to take part equally with men at all levels of decision-making is a human-rights issue. Human-rights standards guarantee women to take part equally and fully in all aspects of economic, political and social life and to get the courage at all levels. The women's happiness of other human rights is dependent on their skill to participate fully in decision making. This study has investigated that what is the Albanian women's rights and how much they take part in politics.
\end{abstract}

Keywords: Politics, participation, decision-making, women's rights

\section{Introduction}

Albania is a country with a young population, and the emigration has influenced the average age of the population.40 percent of the country's population are consist of children and adults. Women in Albania make up more than half of the population, but their role in political events of the country remains insignificant, but comparison with the early years, the participation of Albanian women in politics is increasing. Women can be found in large numbers in educational institutions and that of social welfare but this is not much important regarding to their participation in Parliament, government or institutions of local government. Aggravation of status of women and girls in Albania has brought several non-profit organizations (NPO) for women into sight and that mainly deal with issues that influence women today. According to the USAID reports, most of the NGO's in Albania is focused on issues concerning women and children. Most of advocacy role of women rights is performed by these organizations and supported financially by international donators. However, no systematic effort has been taken to illuminate what happens in other various aspects of private and public life of women. Even that, there is a slight coordination of efforts in NPO sector; ongoing Albanian governments and parliamentary legislation have created a legislation that is sensitive to gender relations and its awareness (Hazizaj, December 2005).

In general women should involve in politics, because the community needs help and they can address the politicians. Those in higher ranks should know what is happening in the communities. It's hard to believe that, half the world's population continues to be sidelined or ignored in the decision-making processes that govern everyday life. From decisions about how the family's money is spent, to how the governments function, women are still facing huge obstacles when they try to give their opinions and affect the decisions that shape their lives. In spite of these obstacles, women and girls seek ways to influence and contribute to the political, socio-economic and cultural development of their communities and countries. They learn how to change the rules of engagement and, in doing so, they are challenging power dynamics and decision-making and tackling poverty.

The percentage of Albanian women that take part in politics and also their rights is investigated in this article.

\section{Organization of Movement of Civil Society for Women}

Period of 1994-1996 was a dynamic period of evolution of movement of women in Albania and reflected promoting political environment that was created because of transition. Nevertheless, there was only small communication among 
groups of NGO's for women created in mid of 1990. During 1995-1999, a gradual process of maturity and creation of network of communication between these groups is seen. Because of their maturity, some networks of groups with certain intentions began to institutionalize. These intentions were: a) undertaking of joint activities (Federation of the Albanian Woman, Millennium); b) cooperation in creation of joint strategies (National Council of the Albanian Woman).Another distinguishing feature of these organizations is their offer of social services for affected categories of the society (SOROS, 2001).

From bank of records that exists in Centre of the Gender Alliance it results that out 110 NGO's for women that are registered, 23 percent of them work as attorneys; 18 percent perform in mission of Woman and Family (children); 11percent work in field of economy; 10 percent in that of culture; 9 percent in information; 6 percent in counseling and direct services; 6 percent of them have rural women as their objective; 4 percent of these NGO's belong to political forums of women; 2 percent are involved in decision making, health, religion, education, media, employment and trafficking. With all of the achievements of women movement in Albania, it still faces challenges and difficulties, moreover such as the rest of the Albanian community. What is noticed is the need for cooperation and coordination of activities, programs and projects with the purpose of increasing impact of these movements in social and political events of the country. Another difficulty noticed by the non-profit organizations is that international donators are leaving. In such terms chances for survival are only few and competition is growing. Continuance of these social services will be possible if only state locally or centrally or business will financially support their activities (Children's Human Rights Centre of Albania, 2006).

Participation of the Albanian women in decision-making processes and in politics in particular remains at a low level, compared to other countries of Eastern and Central Europe. Level of participation of the Albanian women in politics is conditioned by qualities of democratic development of society; from economical, social and cultural development of the country; by heritage and existing mentalities; way of education and of expectation that society has for boys and girls; features of the transition period in Albania, etc. Regarding to the positions in local government, again level of participation remains low. In recent local elections (October 2003) out of 76 candidates (men and women) for city mayor only three women were elected, and for heads of city hall units three of them were elected, so, only 4 percent 61 . While, for the position of the chairman of municipality out of 308 of candidates, men and women, only 6 women were elected, so, only 2 percent. Seats held by women in 2009 national parliament's \% 16.4 (Instat, World statistics pocket book, 2010). The data shows that the Albanian women are interested in politics but the obstacles are preventing them in involving politics.

\section{Participation of Albanian Women in Politics}

From the fall of communism Albania has made enormous steps to change and improve national legislation. After 1992 and up until today almost entire legislation of the communist era has been substituted with new legislation. Despite the fast change and modification, because of the weak institutions of law enforcement, lack of a law abiding culture and lack of knowledge about legislative techniques has rendered a number of laws approved by the parliament inapplicable in real life. One of the main problems of legislation in Albania is not its deficiency but its un-application or execution, a problem that has not yet found a solution but should be addressed to law making and law enforcement institutions.

Albania has accepted a system of legal hierarchy. Constitution is the principal document in the system of legal state in Albania. It serves also as a reference source for creation of other legal and normative acts. Meanwhile, international conventions accepted and ratified by Albania are given priority in execution in comparison to national laws that come second. In 2005, free parliamentary elections for the fifth time were held, and The Democratic Party, first political party won in Albania after the fall of communism. In September of the same year, Sali Berisha was elected Prime minister and his political program consisted on war against organized crime and corruption that in recent years was turned into a barrier for development of Albania. Albania is a Parliamentary Republic and Parliament which is the principal and the only lawmaking organ. It functions through a parliamentary chamber with 140 seats, 100 of them are elected through direct majority vote while 40 of them are elected through nominated lists deposited in advance by political parties. Parliament has one speaker and two vice-speakers. Parliament has nine parliamentary groups that represent political parties of the entire political specter (Hazizaj, December 2005).

Level of representation of women in the government remained low in the 2005th election. In 2005,Albanian government had only one woman minister out of 16 , while it had 7 women as deputy ministers and 21 men as deputy ministers. It was clearly seen that there was a misbalance in including women in political decision-making. The same problem existed at Directorate levels and clerks of public administration. This is more obvious in institutions such as Police and Army, where number of women included in leading positions is low. 
Elections in 2005 marked the lowest level of participation of women in political events of the country. Even that there was a high number of participation of women as candidates for representatives, only 10 of them got elected. According to inter parliamentary union, this put Albania in the last place in Europe and in 114-th place in the world for the number of women as member of the parliament. However, it is worth to mention level of presentation of women in Parliament gradually increased and all ten women representatives in Parliament, through their own initiatives prove that women could play an important role in leading the country. This argument was served by the fact that the speaker of the Parliament of Albania was a woman, and Head of Parliamentary Commission for Education and Means of Public Information was a woman (Albanian Coalition for the Preparation of Alternative Reports, 2010). Out of 101 candidates for representatives from the majority list, only eight of them were elected. Two other women were selected from the proportional list making total of female representative's count only ten out of 140 seats of the Albanian parliament. Women candidates for representatives had to put up with a tough competition during election campaign of 2005. Many women ran for representatives in very difficult areas against tough male candidates. When male candidates were weaker, they turned to a negative pattern of expression against women candidates and sometimes they questioned their moral values .Party with the highest number of female representatives is Socialist Party (4 women) followed by Democratic Party (3women), Social Democrat Party (2 women) and Republican Party (1). Other political parties in the parliament do not have female representatives. It is hard for a woman in Albania to get actively involved in politics. Even that there are positive models of women from all political parties; most of them have to put up with a harsh political environment. Male domination of parliament and of politics renders political language rude and violent, a difficult model to accept from women. Mostly women in politics have listed violence and rude vocabulary as one of the main obstacles to join political life (Hazizaj, "2005 Parliamentary Elections and Human Rights in Albania", December 2005) .

The 2005 elections marked new positive experiences in the field of gender equity, because for the first time in the parliamentary history of Albania a woman was elected in the position of the Chairwoman of the Parliament of Albania. For the first time in these elections, a political force leaded by a woman (Green Party) takes part in the political competition; a woman also is presented as independent candidate. It was also positive the signing of "Code of Behaviour" by political forces on 27 May 2005, an initiative of the President of the Republic of Albania, that showed a de jure approval from these political forces about support and promotion of female candidates.

On the other hand, in the public administration the woman presence is more encouraging considering the fact that they constitute $43 \%$ of the overall number of employees, whereas in the leading level (lawmakers, high rank officials and leaders group) the female occupy $27 \%$. The representation of women and girls in leading positions of political parties is also low. This situation is not caused by their indifferentism to be involved in political affairs and it is not an indicator of women and girls inability in this direction.

In 2005 three main civil organizations initiated creation of Coalition for encouragement of participation of women, youth and minorities in politics. At the beginning of February 2006, the coalition publicly declared an open petition where a minimum quota of 30 percent of participation of women in parliament and in local and central government is required.

In spite of continuous efforts of woman and girls' political organizations to grow their participation in political affairs and as a consequence in decision making, it should be said that their representation in Parliament and in the government still remains low. It is noticed that women and girls have been really very active participators during the electoral campaign. They are very good promoters of their political forces' programs, they carry out well indeed the commissioner's role and they're very strong supporters during the realizations of campaigns, but this representation and this quite active part isn't appreciated from the political forces, as candidate in the parliamentary elections and especially the local ones (General Policies' Directorate, 2009).

The Parliament's Chairwoman, the Prime Minister and the President gave a strong support to increase the participation of women in the political and public decision making. They fully supported the introduction of the quotas in the Electoral Code and gave their important support to the approval of the Law No. 9970, dated July 24th, 2008 "On Gender Equity in the society", since such acts were subject to considerable discussion regarding the introduction of the quota. The appointment of many women in managerial posts in a number of important government institutions shows the increased awareness and the political support to women, as well as to their values and potential (General Policies' Directorate, 2009).

In the election in 2009, there were 23 Women Members of Parliament or $17 \%$ of the whole number of MPs. There were 1 minister, 9 nine vice ministers and 2 general secretaries (Albanian Coalition for Promotion of Women, Youth and Minorities in Politics).

After the June 2009 elections, there were 23 women in the 140-seat Parliament, an increase from nine in the previous parliament. These included the Speaker and one woman in the Council of Ministers. The law mandates that 
women fill 30 percent of appointed and elected positions, and the electoral code provides that 30 percent of candidates should be women. However, not all parties followed the electoral code, and many placed women's names in low spots on the ballot, virtually assuring that they would not win a seat in the parliament under the country's regional proportional parliamentary system in which votes are allocated to candidates in order of their appearance on the ballot (http://www.state.gov/documents/organization). For each of the 12 multi-member electoral zones, at least 30 percent and one of the first three names of the multi-name candidate list must belong to a candidate of the opposite gender (Elections in Albania,June 23 Parliamentary and Local By E, 2013).

The Government's gender policies have had as their objective the empowerment of women's status so that women are granted increasing continued access to the labor market as well as to opportunities for official, political or business career. Seldom, negative opinion is spread on women who are active in politics in high level. At the level of small town and villages, women hesitate to involve in politics while in other cases, women themselves show little trust in females involved in politics. Also, the increasing participation of women in the political and public life of the country and in the decision making processes has offered opportunities that the interests of women be better reflected in taking initiatives for the protection of their rights. Civil society, women political forums and the government mechanism on gender equity, supported by international organizations active in Albania, have made efforts:

1. to increase capacity of elected or potentially to be elected women. In this framework a considerable number of training sessions have been organized and conducted on gender issues, communication, campaigns organization, situation management, etc.

2. increase the awareness of public opinion on the positive values that equal participation of men and women in politics and decision making have for the democratization and development of the country. In this framework, the following has been organized and carried out: awareness broadcasts and spots in electronic media, reports and analysis in the written media, posters, leaflets etc on different topics focusing on women and their concerns (Republic of Albania Ministry of Labor, 2009).

According to the last election result in 2013, 25 women out of 140 seats, take part in the Albanian parliament, which makes 18\% percent (http://www.quotaproject.org/uid/countryview.cfm, 2013). There were 6 women ministers out of 19 ministers, such as: Minister of Defence, Minister of European Integration, Minister for Urban Development and Tourism, Minister of Education and Sports, Minister of Culture, Minister of Innovation and Public Administration (Prime Minister`s Office, 2013).

\section{Conclusion}

Recently there has been observed and enormous steps has been taken about the Albanian women participation in politics and also in management. On the other hand, the handling of such issue by the written or electronic media shows sufficiently on the media awareness regarding the importance of women participation in political and public decision making positions.

The sealing of the quotas in the Electoral Code constitutes another result towards gender equity and especially towards increasing women representation in the highest legislative body, the Albanian Parliament. The participation of women in politics has been supported by the Parliament as well.

The current government makes constant positive efforts to empower and support the women and increase their participation in the political and public decision making. The action plan provides for concrete actions towards such increase for women and girls in political and public decision making, the encouraging of their values and the increase of media and public opinion awareness. The active roles of the women in politics, management and decision making will have impact on improvement of the politics in Albania.

\section{References}

Albanian Coalition for the Preparation of Alternative Reports. (2010). Tirane.

Albanian Coalition for Promotion of Women, Youth and Minorities in Politics. (n.d.). Retrieved September Thursday, 2014, from http://www.crca.al/women-politics/albanian-coalition-promotion-women-youth-and-minorities-politics.

Children's Human Rights Centre of Albania, A. C. (2006). Report of NNO`s on Situation of

Women and Girls in the Republic of Albania. Tirana,: Sida.

Directorate of Policies on Equal Opportunities, Republic of Albania Ministry of Labor, Social Affairs and Equal Opportunities, General Policies' Directorate . (2009).Tirana, Albania.

Elections in Albania,June 23 Parliamentary and Local By E. (2013, June). Retrieved September Tuesday, 2014, from Europe and Asia International Foundation for Electoral Systems: http://www.iemed.org/observatori/recursos/documents/dossiers-especials/ 
Elections in Albania. http://kryeministria.al/en.(2013).Retrieved September Wednesday, 2014, from Prime Minister`s Office. Hazizaj, Altin, (December 2005). Chemonics International, Report on Evaluation of Execution of CEDAW in Albania. Tirana: USAID.

Hazizaj Altin, "2005 Parliamentary Elections and Human Rights in Albania" - National Report for 2005 Parliamentary Elections and promotion of human rights by political parties in Albania, Tirane, December 2005. http://www.state.gov/documents/organization, A. (n.d.). Retrieved September Thursday, 2014.

(http://www.quotaproject.org/uid/countryview.cfm, 2013)Instat. (2010). World statistics pocket book.

Republic of Albania Ministry of Labor, S. A. (2009). Republic of albania. Retrieved September Thursday, 2014, from http://www.unece. org/fileadmin/DAM/Gender/documents/Beijing+15/Albania.pdf

SOROS. (2001, March ). Foundation "Open Society for Albania" 90+10 Woman in the post communist transition, National Conference. 
